\title{
Partial Characterization of a Vicilin-Like Glycoprotein from Seeds of Flowering Tobacco (Nicotiana sylvestris)
}

\author{
Jared Q. Gerlach, ${ }^{1,2}$ Veer P. Bhavanandan, ${ }^{1}$ Paul A. Haynes, ${ }^{3,4,5}$ and Lokesh Joshi ${ }^{1,2}$ \\ ${ }^{1}$ Center for Glycosciences and Technology, Biodesign Institute at Arizona State University, 1001 S McAllister Avenue, Tempe, \\ AZ 85287, USA \\ ${ }^{2}$ National Centre for Biomedical Engineering Science, National University of Ireland, Galway, Ireland \\ ${ }^{3}$ Bio5 Institute for Collaborative Bioresearch, The University of Arizona, Tucson, AZ 85721, USA \\ ${ }^{4}$ Department of Chemistry and Biomolecular Sciences, Macquarie University, North Ryde NSW 2109, Australia \\ ${ }^{5}$ Australian Proteome Analysis Facility, Macquarie University, North Ryde NSW 2109, Australia
}

Correspondence should be addressed to Lokesh Joshi, lokesh.joshi@nuigalway.ie

Received 5 February 2009; Accepted 31 March 2009

Recommended by Andrew Wood

A vicilin-like glycoprotein from the seeds of Nicotiana sylvestris, flowering tobacco, has been identified using nanoLC/ESI-MS/MS. Sequences from a fragment of protein demonstrated homology with vicilins from other members of the Solanaceae family, notably potato (Solanum demissum). Reducing and nonreducing SDS-PAGE analyses of the identified protein indicated that fragments resulting from in situ proteolytic processing are joined by intrachain disulphide bonds. Staining with Con A lectin was specifically inhibited by mannose suggested the presence of $N$-linked glycosylation which was confirmed by carbohydrate compositional analysis of PVDF-bound protein subunits. HPAEC-PAD analysis of the monosaccharides released from the glycoprotein by acid hydrolysis revealed glucosamine and mannose. $N$-acetylglucosamine termination of attached oligosaccharides was further verified by inhibitable WGA lectin staining. Immunostaining of PVDF-bound N. sylvestris proteins with antibodies against G. max total protein demonstrated cross-staining at masses corresponding to fragments from the proteolytically processed protein subunits.

Copyright () 2009 Jared Q. Gerlach et al. This is an open access article distributed under the Creative Commons Attribution License, which permits unrestricted use, distribution, and reproduction in any medium, provided the original work is properly cited.

\section{Introduction}

Solanaceae encompasses many plants that are nutritionally and/or economically important including potatoes, tomatoes, eggplant (all Solanum spp.) and tobacco (Nicotiana spp.). Species of the genus Nicotiana have become leading proof-of-concept laboratory platforms for plant-based biopharmaceuticals [1-6] and have gained popularity as recombinant hosts through the development of successful transformation protocols including viral and bacterial methods [7, 8]. In 1990, tobacco was stably transformed with a gene encoding Streptococcus mutans protein antigen A, demonstrating that plants could be useful as vaccineproducing organisms [7]. Fully functional recombinant antibodies, which may find eventual use as therapeutics, have also been produced in tobacco plants $[9,10]$. Seed deposition of recombinant proteins in tobacco species has also been demonstrated $[9,11,12]$.
Seeds represent a highly desirable depository for recombinant protein products due to their excellent accumulation and stability $[9,11,13]$. Endogenous storage proteins are highly concentrated in seeds and constitute one of the largest caches of non-animal protein in nature. Storage proteins are systematically degraded during germination to ensure a constant supply of nitrogen and carbon-rich intermediates useful for synthesis of new materials $[14,15]$.

Previously, Sano and Kawashima [16] partially characterized the abundant $11 \mathrm{~S}$ (also called legumin) protein component from N. tabacum seeds. As is the case with many nonleguminous, dicotyledonous (dicot) plants, the seed protein content of Nicotiana spp. is composed largely of $11 \mathrm{~S}$ proteins [16]. However, dicot species may also produce large amounts of $7 \mathrm{~S}$ (sometimes $8 \mathrm{~S}$ ) globulins more commonly referred to as vicilins.

Vicilin-type globulins may comprise up to $80 \%$ of protein found in some legume seeds [15, 17], but usually 
constitute a significantly smaller percentage in nonlegumes. Typically, vicilins are sparsely glycosylated trimeric clusters of combined molecular mass between 140 and $190 \mathrm{kDa}$ [18]. Under physiological conditions, vicilin complexes associate without interchain disulphide bonds. However, at higher concentrations, and in the presence of magnesium and calcium ions, they may also form complexes with greater numbers of subunits $[15,19]$. Many vicilins undergo proteolytic modification, or "nicking," and this processing creates a high degree of heterogeneity in the subunit population $[12,20,21]$. Vicilins of adzuki bean (Vigna angularis) have been shown to have trends in thermostability and surface hydrophobicity attributed to posttranslational proteolytic processing [21].

Vicilin subunits contain two cupin domains. Each cupin domain is a 6-stranded, short beta-barrel structure common to several subfamilies of the globulin superfamily of proteins, including the $11 \mathrm{~S}$ storage proteins, to which they are closely related (Figure 1) [15, 22, 23]. Characterized vicilin glycoproteins from dicots soy (Glycine max) [24], pumpkin (Cucurbita maxima) [25], and carrots (Daucus carota) [26] have also been identified as allergens. Vicilin-like proteins from monocotyledonous species with characteristics similar to dicot $7 \mathrm{~S}$ vicilins have been identified in wheat (Triticum spp.), barley (Hordeum spp.), and oat (Avena spp.) [27, 28].

While Higgins et al. [12] noted the presence of endogenous vicilin in their report of recombinant pea (Pisum sativum) vicilin expression in $N$. tabacumseeds, based on cross-reactivity of an antibody fraction made against the pea protein, no characterization of the endogenous protein was carried out at that time. This is the first report, to our knowledge, describing an endogenous, glycosylated, vicilinlike protein from plants of the Nicotiana genus.

\section{Materials and Methods}

2.1. Soluble Protein Extraction. Seeds from Nicotiana sylvestris were purchased from Johnny's Seeds (Winslow, $\mathrm{Me}$, USA). All procedures performed at $4^{\circ} \mathrm{C}$ unless specified otherwise. Seeds $(28 \mathrm{~g})$ were ground to a uniform fine powder in a coffee grinder, and defatted in $100 \mathrm{~mL}$ cold acetone with rapid stirring for 1 hour. The acetone slurry was filtered, and the residue washed with one additional volume of fresh acetone and dried completely under vacuum. $2 \mathrm{~g}$ portions of the dry delipidated seed powder were first extracted using $20 \mathrm{~mL}$ double-distilled water $\left(\mathrm{ddH}_{2} \mathrm{O}\right)$ with gentle shaking for 30 minutes. Albumin-containing supernatant was removed following centrifugation at $4.000 \times \mathrm{g}$ for 15 minutes. To extract the total soluble globulin protein (TSG) the pellet was suspended in $20 \mathrm{~mL}$ of extraction buffer containing $50 \mathrm{mM}$ Tris- $\mathrm{HCl}, 200 \mathrm{mM}$ $\mathrm{NaCl}$, and $0.1 \mathrm{mM} \mathrm{PMSF}, \mathrm{pH} 8.0$ and the slurry continuously inverted for 1 hour. The majority of the insoluble content was removed by centrifugation for 15 minutes at $4.000 \times \mathrm{g}$. Supernatant, in $1.5 \mathrm{~mL}$ aliquots, was further centrifuged $(14.000 \times \mathrm{g}, 30$ minutes) to yield TSG. Extracts from dried uncooked seeds of G. max and C. maxima were prepared using the same extraction buffer and general process but were subjected to neither delipidation nor separate extraction of albumins prior to globulin extraction. Protein content was estimated by Bradford method [29] (absorbance at $595 \mathrm{~nm}$ ) using a Spectramax spectrophotometer (Molecular Devices, Sunnyvale, Calif, USA).

2.2. Size-Exclusion Chromatography. Approximately $2.5 \mathrm{mg}$ TSG prefiltered through $0.22 \mu \mathrm{m}$ acetate membrane (Millipore, Billerica, Mass, USA) was subjected to fast protein liquid chromatography (FPLC) using a Superdex 200 10/30 size exclusion column (GE Health Sciences, Uppsala, Sweden). Isocratic elution was performed at a flow rate of $250 \mu \mathrm{L} / \mathrm{min}$ using $50 \mathrm{mM}$ Tris- $\mathrm{HCl}, 200 \mathrm{mM} \mathrm{NaCl}, \mathrm{pH}$ 8.0. The eluant was monitored by absorption at $280 \mathrm{~nm}$, collected in fractions, and pooled appropriately. Elution calibration was performed using goat IgG (Mr $150 \mathrm{kDa})$, human transferrin $(\mathrm{Mr} 81 \mathrm{kDa})$, and human myoglobin $(\mathrm{Mr}$ $39 \mathrm{kDa})$.

2.3. SDS-PAGE and Enrichment of 7S Proteins. Crude and postsize exclusion TSG was subjected to SDS-PAGE analysis under reducing (R-SDS-PAGE) and nonreducing (NR-SDSPAGE) conditions. Enrichment of $7 S$ proteins was carried out by first separating pooled postsize exclusion protein fractions under nonreducing conditions in $12 \%$ Bis-Tris polyacrylamide gel (Invitrogen, Carlsbad, Calif, USA) followed by direct excision of the nonreduced vicilin $(\mathrm{Mr} \sim 48 \mathrm{kDa})$ band. The excised gel containing the $7 \mathrm{~S}$ protein was macerated to a fine paste in a microcentrifuge tube. The protein was then re-extracted from the paste with the addition of $40 \mu \mathrm{L}$ of $5 \times$ R-SDS-PAGE sample buffer containing $\beta$-mercaptoethanol $\left(\beta\right.$-ME) followed by agitation at $65^{\circ} \mathrm{C}$ for 30 minutes. An additional $20 \% \mathrm{v} / \mathrm{v}$ of $1 \times$ reducing sample buffer was added, the contents vortexed briefly, and the gel pieces sedimented by centrifugation at $5000 \times \mathrm{g}$ for 1 minute. Supernatant containing the reduced protein was loaded onto $4-12 \%$ BisTris polyacrylamide gel and separated in MES running buffer (Invitrogen).

2.4. Protein Sequence Identification. Protein samples were run on $4-15 \%$ Tris- $\mathrm{HCl}$ gels (Bio-Rad) under reducing conditions after completion of size exclusion chromatography. Gels were stained with Coomassie Brilliant Blue (CBB) in a fixative solution containing $0.05 \%(\mathrm{w} / \mathrm{v}) \mathrm{CBB}, 30 \%$ methanol, and $10 \%$ acetic acid and partially destained in $30 \%$ methanol, $10 \%$ acetic acid for protein visualization. Bands of interest were excised and completely destained, macerated in deionized water and subjected to exhaustive trypsin digestion. Peptides were extracted from the gel pieces with $5 \%$ formic acid $/ 50 \%$ acetonitrile, evaporated to dryness in a Speedvac vacuum centrifuge (Savant, Farmingdale, $\mathrm{NY}$ ), and reconstituted in $10 \mu \mathrm{L}$ of $1 \%$ formic acid.

A microbore HPLC system (Surveyor, Thermo, San Jose, Calif, USA) was modified to operate at capillary flow rates using a simple T-piece flow-splitter. Columns $(8 \mathrm{~cm}$ $\times 100 \mu \mathrm{m}$ I.D.) were prepared by packing $100 \AA, 5 \mu \mathrm{m}$ Zorbax C18 resin at 500 psi into columns with integrated electrospray tips made from fused silica, pulled to a $5 \mu \mathrm{m}$ tip using a laser puller (Sutter Instrument Co., Novato, Calif, 


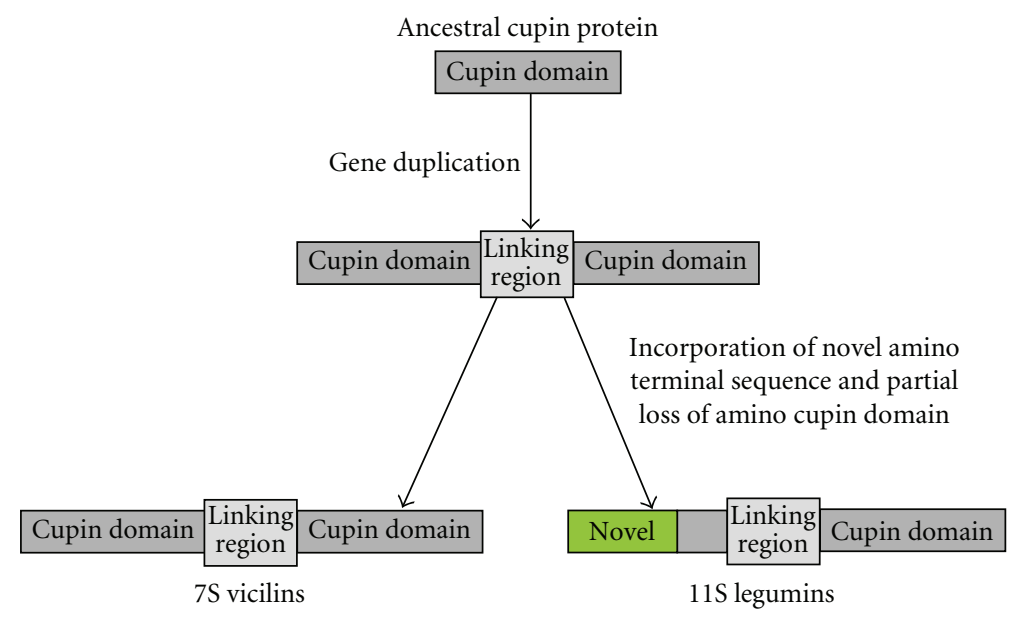

FIGURE 1: Proposed evolutionary link between 7S proteins (vicilins) and 11S proteins (legumins) based on the repeating structure of the cupin domain genes. Diagram modeled after Gibbs et al. [23].

USA). Electrospray voltage of $1.8 \mathrm{kV}$ was applied using a gold electrode via a liquid junction upstream of the column. Samples were introduced onto the analytical column using a Surveyor autosampler (Thermo, San Jose, Calif, USA). The HPLC column eluent was eluted directly into the electrospray ionization source of a Thermo LCQ Deca ion trap mass spectrometer.

Peptides were eluted in a gradient using 5\% acetonitrile, $0.1 \%$ formic acid (buffer A) and 90\% acetonitrile, $0.1 \%$ formic acid (buffer B), at a flow rate of $500 \mathrm{~nL} / \mathrm{min}$. Following an initial wash with buffer A for 10 minutes, peptides were eluted with a linear gradient from $0-50 \%$ buffer B over a 25-minute interval, followed by $50-98 \%$ B over 5 minutes and a 5-minute wash at $98 \%$ B. Automated peak recognition, dynamic exclusion, and daughter ion scanning of the top three most intense ions were performed using the Xcalibur software as previously described [30]: (i) full mass survey scan 400-1500 amu, (ii) MS/MS of most abundant ion from survey scan, (iii) MS/MS of 2nd most abundant ion from survey scan, (iv) MS/MS of 3rd most abundant ion from survey scan. Other instrument parameters included: collision energy 39\%, activation Q 0.25 , activation time 30 milliseconds, isolation width $2.0 \mathrm{amu}$, dynamic exclusion enabled with repeat count 2 , duration 0.5 minute, exclusion duration 5 minutes, exclusion mass width low $1.5 \mathrm{amu}$, high $1.5 \mathrm{amu}$.

2.5. Database Searching, Result Filtering, and Validation. MS/MS data were analyzed using SEQUEST run under Bioworks 3.1 (Thermo, San Jose, Calif, USA) [31, 32]. All spectra were searched against the NCBI nonredundant protein sequence database (downloaded August 2007). Search parameters included peptide and fragment mass tolerance of $2 \mathrm{Da}$ and $0.2 \mathrm{Da}$, respectively, modification of cysteine with $57 \mathrm{amu}$ (iodoacetamidation), and differential modification of methionine with $16 \mathrm{amu}$ (oxidation).

Initial criteria for a preliminary positive peptide identification for a doubly charged peptide were a correlation factor (Xcorr) greater than 2.5, a delta cross-correlation factor $(\mathrm{dCn})$ greater than 0.1 , a minimum of one tryptic peptide terminus, and a high preliminary scoring [33]. For triply charged peptides the correlation factor threshold was set at 3.5, and for singly charged peptides the threshold was set at 1.8. False positive rates for protein identification were assessed using reversed database searching [34, 35]. Imposing a minimum of two peptides per protein on each nanoLC-MS/MS data set [36], no proteins fitting the criteria were detected in the reversed database searches, indicating a protein identification confidence level of greater than $99 \%$ [37].

Peptide sequences identified from the NCBI nonredundant protein sequence database were used with the BLAST algorithm $[38,39]$ to find homologues. Homologues with greatest identity and greatest amount of characterization were considered. FASTA amino acid sequences were aligned using the ClustalW alignment tool (http://align.genome.jp/). Isoelectric point and mass estimation were performed using the ExPASy online algorithm (http://www.expasy.ch/tools/pi_tool.html).

2.6. Transfer of Proteins to PVDF and Lectin Staining. $15 \mu \mathrm{g}$ of protein per well was loaded onto $4-15 \%$ Tris- $\mathrm{HCl}$ gels (Bio-Rad) and electrophoresed for approximately 1 hour at $50 \mathrm{~mA}$ (starting potential $150 \mathrm{~V}$ ). Proteins were transferred to sequencing grade polyvinylene diflouride (PVDF) $0.45 \mu \mathrm{m}$ membrane (Millipore) in a semidry transfer apparatus (Bio$\mathrm{Rad}$ ) at $1.5 \mathrm{~mA} / \mathrm{cm}^{2}$ for 2 hours at a maximum of $15 \mathrm{~V}$. Prior to transfer, PVDF was washed twice in 100\% methanol and rinsed in transfer buffer. Blots were used directly after transfer or washed in $\mathrm{ddH}_{2} \mathrm{O}$ and dried for storage at room temperature for later use.

Concanavalin A (Con A lectin) conjugated to alkaline phosphatase (EY Laboratories, San Mateo, Calif, USA) was used to probe for $N$-linked oligosaccharides. PVDF membranes with bound proteins from seeds of $N$. sylvestris were washed in $20 \mathrm{mM}$ Tris- $\mathrm{HCl}, 100 \mathrm{mM} \mathrm{NaCl}, 0.05 \%$ 


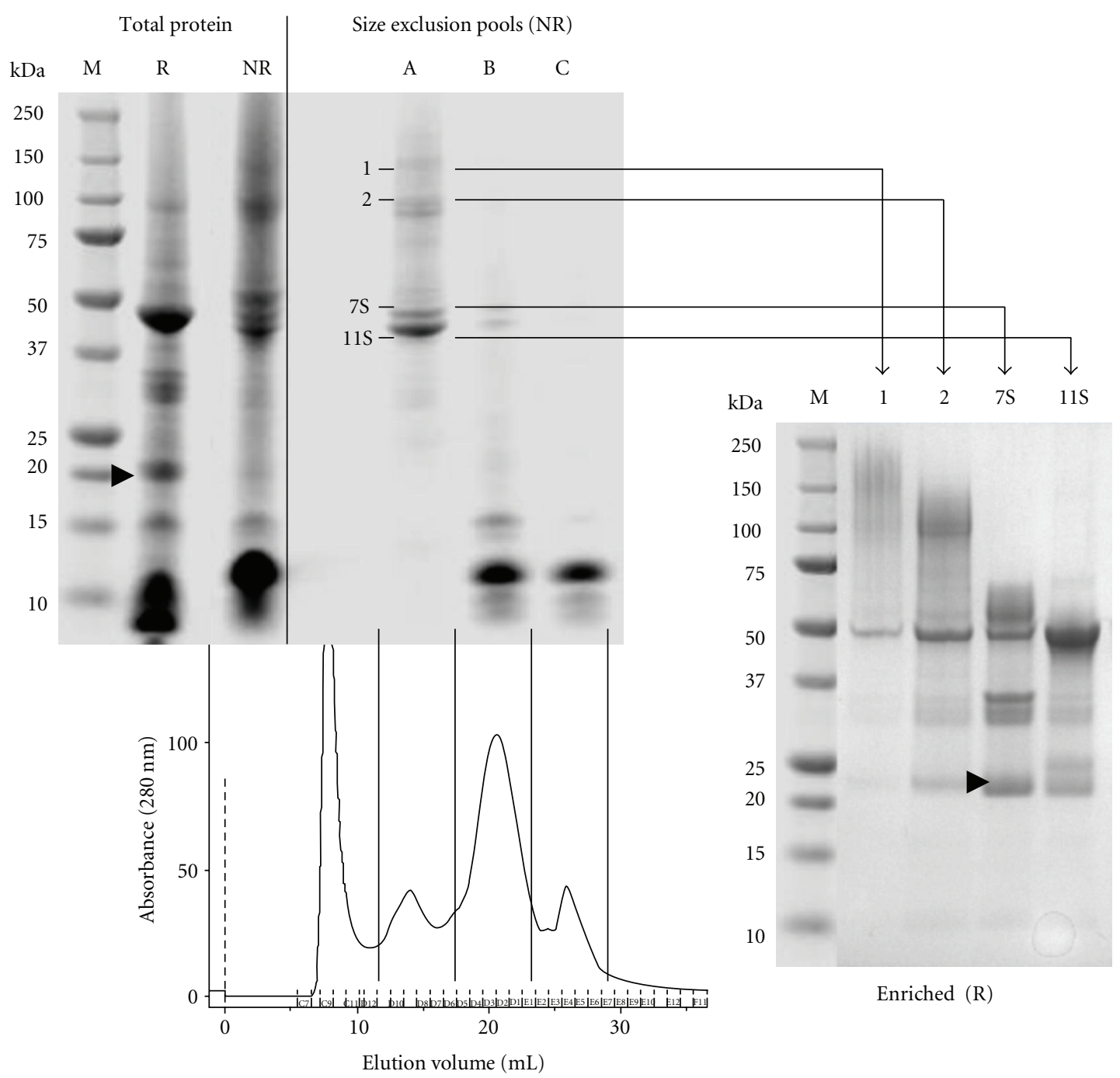

FIGURE 2: SDS-PAGE of N. sylvestris total protein under reducing (R) and nonreducing (NR) conditions. Size exclusion pools A, B, and C under nonreducing conditions showing relative positions of possible trimeric (1) and dimeric complexes (2) and 7S and 11S monomers. Enriched fractions prepared under reducing conditions showing separation of disulphide-dependent components, lanes 1, 2, 7S, and 11S. All gels 4-12\% Bis-Tris. Protein was visualized by CBB staining. Arrowheads indicate the position of band excised for mass spectrometric analysis.

Tween 20, pH 7.4 (TBST), and then blocked for 1 hour in $1 \%$ porcine gelatin (Sigma-Aldrich, St. Louis, Mo, USA) in TBST. After washing twice (all washes 10 minutes) in TBST and once in lectin buffer (TBST plus $1 \mathrm{mM}$ concentrations of $\mathrm{MgCl}_{2}, \mathrm{MnCl}_{2}$, and $\left.\mathrm{CaCl}_{2}\right)$, Con A in lectin buffer $(20 \mu \mathrm{g}$ in $15 \mathrm{~mL}$ ) was added to the blot and incubated for 1 hour at room temperature with gentle agitation. A control blot was incubated in an identical manner with the addition of $10 \mathrm{mM}$ mannose (Sigma-Aldrich) in the lectin buffer. After incubation in lectin solution, the blot was washed twice with TBST and once with $\mathrm{ddH}_{2} \mathrm{O}$. Lectin binding was visualized colorimetrically by reaction of BCIP/NBT (SigmaAldrich) and was stopped by addition of water. Alkaline phosphatase conjugated WGA (EY Labs) was used with the same protocol with the exception of the inhibitory procedure which consisted of preincubation of the lectin in $100 \mathrm{mM}$
GlcNAc for 1 hour prior to and $10 \mathrm{mM}$ GlcNAc during the membrane incubation. Blots were dried at room temperature in the absence of light prior to being scanned with white light and stored as digital files.

2.7. Immunostaining. Polyclonal antibody prepared against G. max total seed protein (S2519, Sigma-Aldrich) was used to probe PVDF-bound proteins for cross-reactivity. SDS-PAGE samples of G. max, C. maxima, and N. sylvestris proteins as well as control proteins. Protein samples were prepared with $\beta$-ME as mentioned previously and separated in 4$12 \%$ Bis-Tris gel (Invitrogen). Control samples consisting of human transferrin, bovine fetuin, bovine serum albumin (BSA), asialofetuin, peanut lectin (PNA), and ribonuclease B (all Sigma-Aldrich) were prepared in the same manner. After protein was transferred to PVDF, the membranes were 


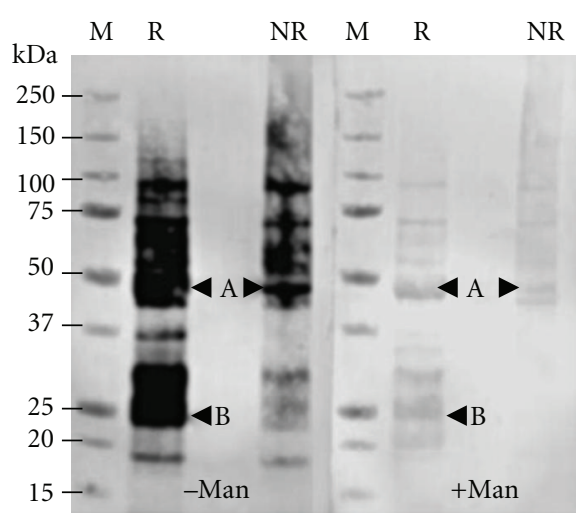

Figure 3: Con A staining without (-Man) and in presence of $10 \mathrm{mM}$ mannose (+Man). Both blots show N. sylvestris seed protein after size exclusion chromatography with (R) and without (NR) $\beta$ ME. A and B indicate position of vicilin bands used for the TFA hydrolysis and subsequent HPAEC-PAD carbohydrate analysis. 4$15 \%$ Tris- $\mathrm{HCl}$ gel transferred to PVDF.

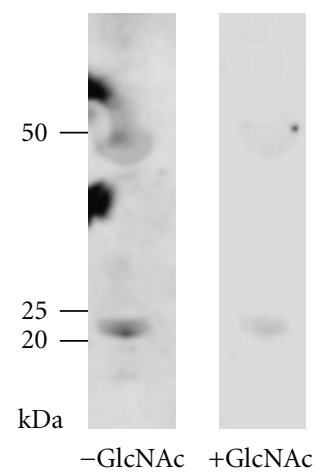

Figure 4: Protein from size exclusion pool A under reducing conditions stained with WGA (-GlcNAc). Inhibition through a combined $100 \mathrm{mM}$ preprolonged and $10 \mathrm{mM}$ prolonged incubation with GlcNAc is shown in comparison $(+\mathrm{GlcNAc})$.

washed for 10 minutes in PBST $(20 \mathrm{mM}$ phosphate buffer, $140 \mathrm{mM} \mathrm{NaCl}, 20 \mathrm{mM} \mathrm{KCl}, 0.05 \%$ Tween 20 , pH 7.4) prior to blocking for 30 minutes in $1 \%$ BSA + PBST. Antibody was used at 1 : 2000 dilution in PBST, and incubation time was 1 hour at room temperature with gentle shaking. Membranes were washed in PBST twice for 5 minutes prior to the addition of secondary antibody against rabbit IgG (A3812, Sigma-Aldrich), conjugated to alkaline phosphatase, used at a concentration of $1: 10000$ in PBST. BCIP/alkaline phosphatase reaction was stopped by addition of water. The blot was rinsed twice for 30 seconds in $\mathrm{dd}_{2} \mathrm{O}$ and allowed to dry at room temperature in the dark prior to being scanned with white light and stored as a digital image.

2.8. Carbohydrate Analysis. Unstained protein bands were excised from PVDF membrane and hydrolyzed in sealed glass ampules containing $4 \mathrm{~N}$ trifluoroacetic acid (TFA) for 3 hours at $100^{\circ} \mathrm{C}$. As a positive control for the hydrolysis conditions, bovine fetuin (Sigma-Aldrich) was also subjected to TFA. To correct for background, identical portions of PVDF from buffer control lanes were subjected to TFA hydrolysis. Hydrolysates were neutralized by dropwise addition of $0.5 \mathrm{~N}$ sodium hydroxide and dried in a vacuum centrifuge (Labconco, Kansas City, Mo, USA). Dry carbohydrates were reconstituted in $100 \mu \mathrm{L}$ HPLC grade water prior to high-pH anion exchange chromatography with pulsed amperometric detection (HPAEC-PAD, Dionex, Sunnyvale, Calif, USA). $20 \mu \mathrm{L}$ aliquots of the carbohydrate solutions were separated on a CarboPac PA10 column $(4 \times 250 \mathrm{~mm}$, analytical $)$ preceded by an amino trap column $(4 \times 50 \mathrm{~mm})$ to minimize interference from protein degradation (Dionex, Sunnyvale, Calif, USA). Isocratic elution of $18 \mathrm{mM} \mathrm{NaOH}$ was performed at a flow rate of $1 \mathrm{~mL} / \mathrm{min}$ over 18.5 minutes at a column temperature of $25^{\circ} \mathrm{C}$. A standard panel consisting of fucose (Fuc), galactosamine (GalN), glucosamine (GlcN), galactose (Gal), glucose (Glc), and mannose (Man) was used as a reference.

\section{Results}

3.1. Protein Extraction and Visualization. $200 \mathrm{mM} \mathrm{NaCl}$ was used during the protein extraction due to the insignificant increase in solubility with $500 \mathrm{mM} \mathrm{NaCl}$ and to aid in downstream analysis and processing. Soluble globulin protein was readily extracted from $N$. sylvestris seeds at slightly alkaline $\mathrm{pH}$, but solubility dropped sharply below $\mathrm{pH}$ 8.0. Although tris-(hydroxymethyl)-aminomethane (Tris) is a weak chelator, no additional measures were taken to sequester metal ions during protein extraction. Solubility reached a maximum of approximately $5 \mathrm{mg} / \mathrm{mL}$ at $4^{\circ} \mathrm{C}$ at which point aggregates of protein began to form and precipitate. The presence of free $\mathrm{Mg}^{2+}$ and $\mathrm{Ca}^{2+}$ ions may have been a limiting factor on the maximum total protein solubility [40]. R-SDS-PAGE of TSG produced one major band at approximately $48 \mathrm{kDa}$ and several bands between $\sim 31$ and $\sim 35 \mathrm{kDa}$ and between $\sim 20$ and $\sim 23 \mathrm{kDa}$ as well as many smaller polypeptides which were poorly resolved (Figure 2, Total protein, lane R). A separation of protein aggregates $>300 \mathrm{kDa}$ by centrifugation in $300 \mathrm{kDa}$ molecular weight cut-off (MWCO) spin filters resulted in a pellet which could be resolubilized to give a similar protein profile to the total extract (data not shown), leading to the conclusion that the globulins aggregate into poorly soluble, high molecular mass complexes when in high concentration as noted by Freitas et al. [14]. A portion of the protein also aggregated after heat denaturation with SDS and did not readily migrate within polyacrylamide gel, resulting in streaking and areas of poor resolution at relative masses greater than $75 \mathrm{kDa}$ as shown in Figure 2 (Total protein, lanes R and NR). Molecular masses corresponding to complexes of proteins $(\sim 100$ to $200 \mathrm{kDa}$ ) were visualized in the gel and were prevalent in the total protein mixture (Figure 2, Total protein, R and NR and in size exclusion pool A, bands 1 and 2).

3.2. Size Exclusion Chromatography and SDS-PAGE. Size exclusion chromatography was used as preparative separation method for TSG. Isocratic elution from size-exclusion media via FPLC produced three major peaks in the $280 \mathrm{~nm}$ absorbance curve (Figure 2, Size exclusion pools A, B, and C) 
- - - MGKGLTF LLVLVLV I SVKGYEEEE SGS - EGSGRK - . - - - - . - . - . - MGS YRKF L L I L L L LVVV SVGT S YEVGEDEKWGEG - . - . - . MKQRAKMWKKEALVML L I I AVLGNA I G I KEEAEAAE E EWWREREEERE F - . - . - . - KTT L L L L L FVLCHGVATTTMAFHDDEGGDKKS PK - . - . - $: *:$ :

51 - - - - LF I LHDSVEVVKS EAGGMKVVKG I TG - - - - - KFVDKPMH I GF I YME - - - - L F L LHDS KE I VRTDAGVMRVV S KGGF SGGGV S I FQS PMH I GF I TME RS KEQF L LEDSKRV I ETEAGEMRV I RS PAS - - - - R I LDRPMH I GF I TME - - - S L F LMSNS TRVFKTDAGEMRVLKSHGG - - - - - R I FYRHMH I GF I SME

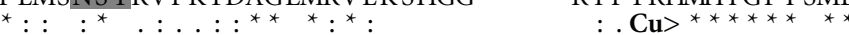

101 PKS LFDPQYLDSNL I L F I RR - . . . . . . . . . . . . . . . GEAK PNT L F I PQY INAHLT L LVRRGVE LVDY LNFQL EVHPE P LVFHF L I PGETR PKS LFVPQYLDS S L I L FVRR . . . . . . . . . . . . . . . . . . GEVK PKS LFVPQYLDSNL I I F I RR - . . . . . . . . . . . - - GEAK ${ }^{\star}::^{\star *}{ }^{*}:::^{\star}:::^{\star *} \quad * \star$ :

151 VGS I RNDKLVEQDLKTGDI YT IDAGSVFY I ENTGEGQRLQI I CS IDT S E S I GH I YKDDF TERRL KEGDVY S I RAGSAFYLVNPAEGQRLH I I CS I SNSNT VGL I YKDE LAERRMKGGDVYR I PAGSVF YMVNVGEGQRLQ I I CS IDKS E S LGF I YDDE LAERRLKTGDLYMI P SGSAF Y LVN I GEGQRLHV I CS I DP S T S

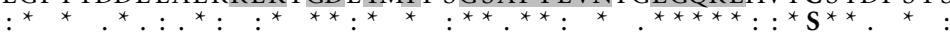

L TWHAFQS F F I GGGRNP S S I LAGFDKET L S TAF LGLYGFQS F F I GGG I YPT S I L SGFDS LT L STAF

VSELEEFLSPEPSG SEEVSE I LTRQL SG L S YGT FQS F F I GGGTY PV SVLAGFDQDT LATAFNV SYTE LRR I L S RQRQG LGLET FQS FY I GGGANSHSVL SGF EPA I LETAFNE SRTVVEE I F S KE LDG

251 A I VY I S P - E SK S PNLWTHF INLEHHOKKAHLKKFVLF EGDVDVTE SKEER A I VP LNTTQS PT P S IWANF LNL EQHQRHDHL KRVVHLE E EAS F E EEDEER P I VYVSDTE S PG - - VWS KF LQVKDGDKGNK I AN I NEDGE EAEKNKP - - - P IMFVDDSHAP S - - LWTKF LQLKKDDKEQQLKKMMQDQE EDE E EKQ - - - -

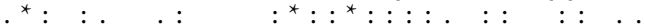

- - - P SWS LGKLVKS L F INENKENKD - - - - KVRDSGDDVYNLYD - RNPDF EQQPTWS L RKLMNNL FGHEGNKRKKGDEGRRGSGKGPDS YNL FD - RKPDY - - - - -WSWRNLVS L I FGNENRDKTKR - - - - TRTGKS PDSYNLYD - KTPDF - - - T S RSWRKL LETVFGKVNEK I ENK - - - - DTAGS PAS YNL YDDKKADF $\mathrm{Cu}>^{* * *}:{ }^{*}: .^{*}:$

351 QNS YGWS LAVDD SQYKP LNHSG I GVY LVNLTAGSMMAPHINPTA S EYG I V KNDYGWS LA LDQS EY S P L KHSD I G I Y LVNL SAGAMMA PH INPTAT EYG I V SNAYGWS VA LDEHEY S P L GHS G I GVY LVNL TAG SMMAPH I NPTAAE YG I V KNAYGWS KALHGGEY P P L S E PD I GV L LVKL S AG SMLAPHVNP I SDEYT I V

401 LRGSGS I Q I VF PNGT LAMNTKVNEGDVFWI PRYFHSVKFHQEQAPWS F FG LRGSGS I Q I VY PNGT L AMNA I VNEGDVFWVPRYF P F CQ I A S RTGP F E F FG LRGTGT I Q I VY PNGT S AMDTEVT EGDV FWVPRYF P FCQ I A S RTGP F E F FG L SGYGE LHI GY PNG SRAMKTK I KQGDVFVVPRYFP FCQVA S RDGP L E F FG

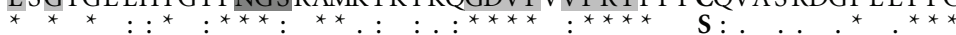

451 FTT S SQRNHPQF LVGRGS L FQTMFGRE LVV S FGS TEKKF EKF I YAQNE ST FTTTARKNMPQF LVGQNS I LQSMRGP EFATAFGV S ERLRR I LDAQREAV FTT S S RRNRPQF LACANS I FHT LR S PAVATAFD I TEDDLDRL L S AQYEVV F S T S ARKNKPQF LAGAA S L LRT LMGP E L S AAFGV S EDT LRRAVDAQHEAV

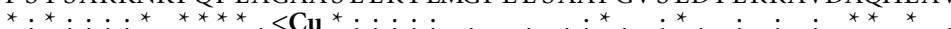

501 I L STASVAPPDDVN _ . . . . . . . - RV I LKKGKREKMI PKLAKKL SND I LP S AS I AP S E PMDPRGEEE EGERGEKGKEKEKMKDVMK I PEV I KS LGND I LPSAE I AP PHKEEEK - - . - . - - RRRREEGRRERERE SEREREEEWTR I L P S AWAAP PENAG - . - . . . . . . - . KLKME E E PNA I R S FAND

S. demissum

C. maxima

G. $\max$
D. carota
S. demissum
C. maxima
G. $\max$

D. carota

$S$. demissum

C. maxima

G. $\max$

D. carota

S. demissum

C. maxima

G. $\max$

D. carota

S. demissum

C. maxima

G. $\max$

D. carota

S. demissum

C. maxim

G. $\max$

D. carota

S. demissum

C. maxima

G. $\max$

D. carota

S. demissum

C. maxima

G. $\max$

D. carota

S. demissum

C. maxima

G. $\max$

D. carota

S. demissum

C. maxima

G. $\max$

D. carota

S. demissum

G. $\max$ gi 1276946 | gb | AAC15238.1 | glob

gi 48210049 gb | AAT40548.1 [_Put

gi 691752|dbj| BAA06186.1| prep

gi 12697782 | dbj| BAB21619.1|_al

S. demissum

$\begin{array}{ll}\text { VVMDVF } & \text { G. } \max \end{array}$

Figure 5: ClustalW alignment of sequences from D. carota, S. demissum, C. maxima, and G. max. Amino acids in bold print represent sequences obtained from putative vicilin of $N$. sylvestris where light gray sections indicate identical amino acids. Asterisks $(*)$ under sequences indicate identically conserved residues while double dots (:) indicate conserved substitutions, and singe dots $(\cdot)$ indicate semiconserved substitutions. Approximate beginning and ending of each cupin domain are indicated by $\mathrm{Cu}>$ or $<\mathrm{Cu}$, respectively. Cysteine residues are shown in bold print and marked by $S$. $N$-glycosylation sites (Asn-Xaa-Ser/Thr) are marked in gray boxes. 


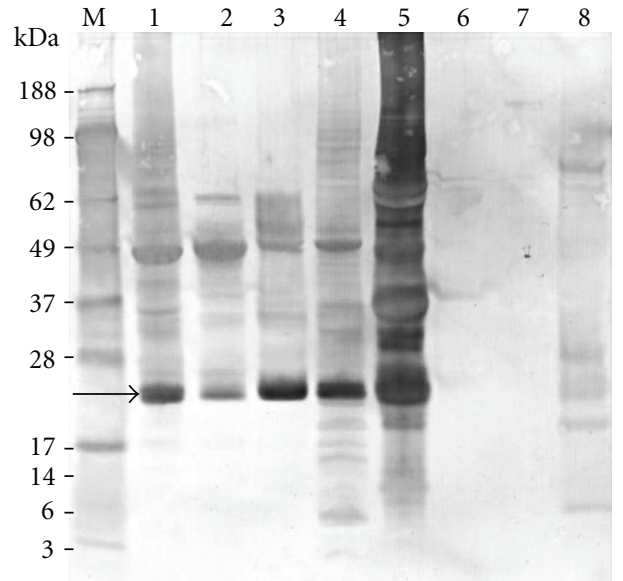

Figure 6: Cross-reactivity of anti-G. max IgG. Lane M, mass marker; lane 1, total soluble protein from N. sylvestris; lane 2, 11Senriched fraction from $N$. sylvestris; lane 3, 7S (vicilin)-enriched fraction from N. sylvestris; lane 4, total soluble protein from $C$. maxima; lane 5, total soluble protein from G. max; lane 6, bovine serum albumin; lane 7 , bovine fetuin; lane 8 , mixed animal and plant protein control consisting of human transferrin $(\sim 75 \mathrm{kDa})$, bovine serum albumin $(\sim 62 \mathrm{kDa})$, asialofetuin $(\sim 50 \mathrm{kDa})$, peanut lectin $(\sim 25 \mathrm{kDa})$, and ribonuclease $\mathrm{B}(\sim 20 \mathrm{kDa})$. Arrow indicates position of homologous allergens from $G . \max (23 \mathrm{kDa}$ peptide from $\mathrm{Bd} 28 \mathrm{~K}$ ) and C. maxima (MP27/MP32). 4-12\% Bis-Tris gel transferred to PVDF.

with the largest percentage of proteins eluting together over a range of $140-160 \mathrm{kDa}$ in pool A. Post-size-exclusion fractions of the protein demonstrated a similar NR-SDS-PAGE profile in comparison to total soluble protein (Figure 2, lane NR versus size exclusion pool A), although the number of major bands present under nonreducing conditions was significantly less in the post size-exclusion pool A. Nonreducing conditions produced a pair of distinct bands at $\sim 44 \mathrm{kDa}$ and $\sim 48 \mathrm{kDa}$ (Figure 2, Size exclusion pool A, bands $7 S$ and 11S).

Based on the previous characterization of the $11 \mathrm{~S}$ proteins from $N$. tabacum [16], it was surmised that the $\sim 44 \mathrm{kDa}$ band is $11 \mathrm{~S}$ protein (Figure 2, Size exclusion pool A, band 11S).

Attempted anion exchange separation of intact $7 \mathrm{~S}$ proteins resulted in poor resolution and considerable precipitation on the column (data not shown). Alternatively, for the purpose of this initial characterization, an enrichment step for the individual protein fractions was performed using a two-step SDS-PAGE procedure following size-exclusion chromatography. Individual bands were isolated from the post-size-exclusion NR-SDS-PAGE gel as indicated (Figure 2, Size exclusion pool A, bands 1, 2, 7S, and 11S), treated with $\beta$-ME, and electrophoresed a second time (Figure 2, Enriched).

Protein bands at $\sim 100 \mathrm{kDa}$ and $\sim 150 \mathrm{kDa}$ Mr which may have, respectively, represented di- and tri-meric complexes comprised of $\sim 50 \mathrm{kDa}$ structures are visible in both NR-SDSPAGE (Figure 2, Size exclusion pool A, bands 1 and 2) and R-SDS-PAGE (Figure 2, Enriched, lanes 1 and 2) gels. It is
TABLE 1: Ion proportion and mass to charge $(\mathrm{m} / \mathrm{z})$ data from nanoLC/ESI-MS/MS for the corresponding sequences identified.

\begin{tabular}{lcl}
\hline Ion proportion & {$[\mathrm{m}+\mathrm{H}]^{+}$} & Sequence \\
\hline 83.3 & 1180.85 & R.LKEGDVYSIR.A \\
67.9 & 1580.69 & R.AGSAFYLVNPAEGQR.L \\
75 & 1448.06 & H.INPTATEYGIVLR.G \\
80 & 1318.73 & I.VNEGDVFWVPR.Y \\
\hline
\end{tabular}

unlikely, however, that these are complexes of $7 \mathrm{~S}$ proteins based on the subsequent R-SDS-PAGE patterns (Figure 2, Enriched, lanes 1 and 2). R-SDS-PAGE of the excised and enriched 7S band (Figure 2, Size exclusion pool A, band 7S) displayed a large diffuse band above $50 \mathrm{kDa}$, a small but distinct band at $\sim 48 \mathrm{kDa}$, and several fragments between 20 and $37 \mathrm{kDa}$ (Figure 2, Enriched, lane 7S).

3.3. Sequence Identity and Comparison. Bands excised from R-SDS-PAGE gels were subjected to trypsin digestion and subsequent mass spectrometric analysis by nanoLC/ESI-MSMS. Four sequence fragments were identified from a protein band of $\sim 22 \mathrm{kDa}$ (Figure 2, Total protein, lane R, arrow and Enriched, lane 7S, arrow) as shown in Table 1. The four masses were found to entirely match portions of the sequence from the putative vicilin protein from Solanum demissum. Of these, two were adjacent and the sequences overlapped by two residues. From the NCBI nonredundant protein database, there were no additional identical hits for the individual sequences obtained from MS/MS. A number of less homologous matches, including nonstorage proteins and functional proteins and precursors, were identified when each sequence component was compared to sequences from other members of Solanaceae (not shown).

3.4. Lectin Blotting and Carbohydrate Analysis. Concanavalin A (Con A) has a high affinity for mannose [41] found in $N$-linked oligosaccharide chains. Staining of N. sylvestris seed protein with Con A (Figure 3 ) was readily inhibited by the addition of $10 \mathrm{mM}$ mannose to the incubation buffer. Monosaccharides hydrolyzed from PVDF-bound bands (unstained) after R-SDS-PAGE separation of N. sylvestris protein were analyzed by HPAEC-PAD. Quantities of each monosaccharide (picomoles) were then used to establish a ratio in relation to Man as shown in Table 2. Deacetylation of amino sugars occurs as a result of the TFA hydrolysis, and the resulting peaks corresponding to GlcN and GalN are representative of $\mathrm{N}$-acetylglucosamine (GlcNAc) and $\mathrm{N}$ acetylgalactosamine (GalNAc), respectively. The monosaccharide profile of the $\sim 48 \mathrm{kDa}$ mass and smaller proteolytically processed components $(\sim 20-24 \mathrm{kDa})$ showed the presence of differing glycosylation among these populations (Table 2). Glc, which is a ubiquitous contaminant, was also present and was not evaluated. No evidence of Fuc was present.

WGA lectin, which has been reported to bind to GlcNAc residues [42], was used to probe the post-sizeexclusion pool A proteins. The pool A protein was separated 


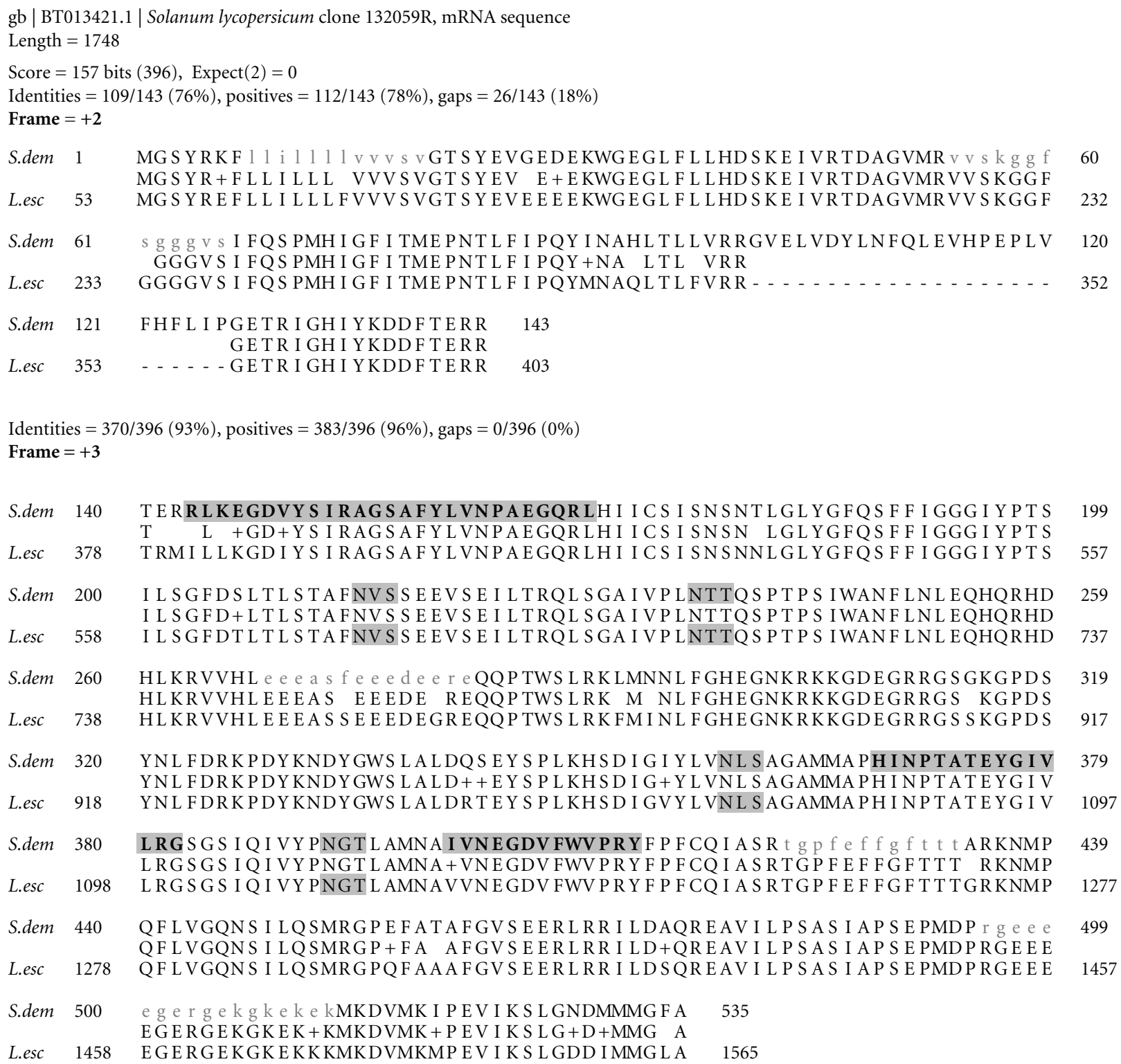

FIgURE 7: Split comparison of $S$. demissum putative vicilin sequence with mRNA-derived in silico polypeptide from S. lycopersicum (tBLASTn). Top, comparison of the first 143 amino acids from S. demissum sequence to the amino end of the derived S. lycopersicum polypeptide from nucleotides 53 through 403 . Bottom, comparison between S. demissum amino acids 140-535 and the cupin domain of the in silico translation of $S$. lycopersicum carboxy domain nucleotides 378 through 1565 . Bold amino acids in grey blocks are those identified from N. sylvestris. Potential Asn-Xaa-Ser/Thr glycosylation sites are marked by grey box. Small letters represent regions subjected to repeatmotif filtering during BLAST execution.

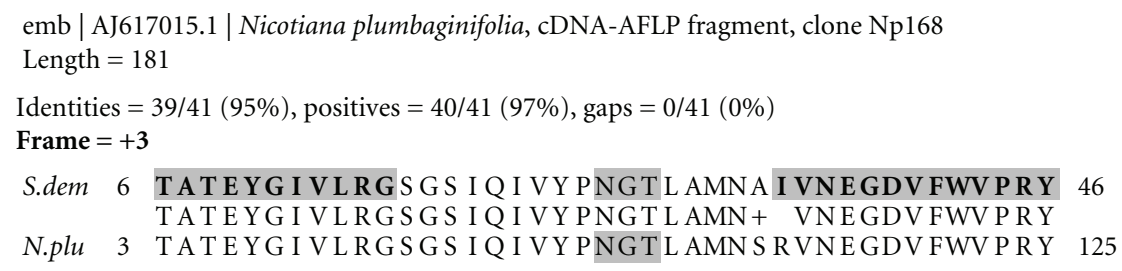

FIgURE 8: Alignment of $S$. demissum sequences with cDNA-derived fragment from N. plumbaginifolia. Bold amino acids in grey blocks represent fragments of peptide identified from N. sylvestris. Asn-Gly-Ser/Thr glycosylation site is marked by grey box. 
TABle 2: Compositional analysis of monosaccharides hydrolyzed from PVDF-bound components of post-size-exclusion N. sylvestris protein. Values represent picomole ratios for each monosaccharide relative to Man for each sample.

\begin{tabular}{lcccc}
\hline Sample & Man & GlcN & GalN & Gal \\
\hline A & 1.00 & 1.88 & 0.08 & 0.08 \\
B & 1.00 & 0.85 & 0.04 & 0.04 \\
\hline
\end{tabular}

via R-SDS-PAGE and transferred to PVDF. Although the band at $\sim 48 \mathrm{kDa}$ was lightly stained by WGA, prominent staining of bands between 20 and $25 \mathrm{kDa}$ was observed (Figure 4). Staining was inhibited by preincubating the lectin followed by sustained presence of $10 \mathrm{mM} \mathrm{GlcNAc}$ in the blot incubation, indicating a legitimate carbohydrate-mediated binding between the PVDF-bound glycoproteins and WGA (Figure 4).

Prediction of glycosylation for a portion of the $S$. demissum vicilin incorporating sequences obtained from $N$. sylvestris, shown in Figure 5, indicated a possible $N$-linked site (Asn-Gly-Ser/Thr). The lack of defined mass to charge $(\mathrm{m} / \mathrm{z})$ for a peptide sequence at this region in the N. sylvestris protein spectra was most likely due to the presence of the oligosaccharide during MS analysis. Further comparison of amino acid sequences from G. max, C. maxima, D. carota, and $L$. esculentum (from the mRNA), to the $S$. demissum peptide sequence confirms that the glycosylation point within the cupin domain at the carboxy end of each of these peptide chains is highly conserved (Figure 5).

3.5. IgG Cross-Reactivity. The hypothesis that sequence homology alone may be an indicator of antibody crossreactivity was explored by immunoblotting. An IgG fraction prepared against G. max total seed protein was used to probe PVDF-bound extracts from $N$. sylvestris and C. maxima. Anti-G. max IgGs bind to proteins from C. maxima seeds and N. sylvestris (Figure 6). Staining of N. sylvestris protein is most intense at molecular masses between 20 and $25 \mathrm{kDa}$ and also corresponds to the known vicilin proteins and fragments from C. maxima (MP27/MP32) and G. $\max (\mathrm{Bd}$ $28 \mathrm{~K}$ and $23 \mathrm{kDa}$ glycopeptides from that protein) (Figure 6, arrow), reinforcing the possibility that vicilin proteins from tobacco may be similar immunogenic agents. Further testing of N. sylvestris protein samples with sera from presensitized individuals was not undertaken in this study.

\section{Discussion}

A glycoprotein from the seeds of N. sylvestris has been identified that it undergoes proteolytic cleavage and exhibits homology with vicilin proteins from other members of Solanaceae as well as other plant families. The protein forms intrachain disulfide bonds, forms noncovalently bound complexes of high molecular mass, has asparagine-linked glycosylation and is recognized by antibodies raised against total seed protein from G. max.

One of the hallmarks of the $7 \mathrm{~S}$ vicilin protein family is the lack of cysteine residues and resulting interchain disulphide bonds. The putative vicilin protein identified from N. sylvestris does, however, form intrachain disulphide bonds which can be broken under reducing conditions. Observation of the presence of cysteines in the sequence of the $S$. demissum vicilin to which the $N$. sylvestris protein fragments share homology indicated the possibility of interchain disulphide bonding between residues near the middle and toward the carboxy terminus of the polypeptide chain as indicated in Figure 5 (marked $S$ below alignment). It can be inferred from this that proteolytic activity must occur at a midpoint between these two cysteines as the addition of $\beta$-ME resulted in separation of polypeptides with masses less than those observed after the initial NR-SDS-PAGE separations. Vicilins from C. maxima and G. max share these cysteine residues at conserved positions, although it should be noted that the $D$. carota protein, which was reported to be isolated from tap root tissue instead of seeds, has only one cysteine residue within the cupin domain at the amino end and no cysteine residues in the carboxy cupin domain as shown in Figure 5.

Although vicilins from D. carota (AAC15238) and G. max (BAB21619) have two complete cupin regions and vicilin symmetry as a result of this, the vicilin from $S$. demissum (AAT40548) varies in that the amino-terminal cupin region is incomplete at the amino end and incorporates a 26amino acid insertion. Although insertions such as this have been proposed [23] as the evolutionary mechanism that led to the emergence of the extant structure of $11 \mathrm{~S}$ seed proteins (Figure 1), the S. demissum protein shares more significant identity with $7 \mathrm{~S}$ proteins (as evidenced through sequence comparison, data not shown). A search for nucleotide homology (tBLASTn) limited to the family Solanceae produced a nearly identical match for the carboxy and amino terminal gene sequences of vicilin mRNA from S. lycopersicum (Figure 7), and a cDNA fragment from $N$. plumbaginifolia, commonly referred to as "Tex-Mex" tobacco (Figure 8). In silico translation of the mRNA from S. lycopersicum (BT013421.1) resulted in a polypeptide containing one partial cupin domain. This domain, which is toward the carboxy terminus of the peptide, has 93\% identity and 96\% homology with the putative S. demissum vicilin (Figure 7). At the amino end, the first 143 amino acids of $S$. demissum vicilin gave an identity of $76 \%(109 / 143)$ and homology of $78 \%(112 / 143)$ when compared to the S. lycopersicum sequence. Comparison of the sequences also revealed the highly conserved $N$-linked glycosylation site found in each of the other vicilins examined here.

The theoretical isoelectric point (pI) of the complete S. demissum vicilin sequence is 5.9 as determined by using the ExPASy online algorithm. In comparison, vicilin-like proteins from N. sylvestris were poorly solubilized below $\mathrm{pH}$ 7.5 and nearly insoluble at $\mathrm{pH}$ 6. The rapid decrease in solubility below $\mathrm{pH} 8$ corresponds well with the findings detailed in a proteome analysis of endosperm and embryos from S. lycopersicum in which vicilin-like proteins isolated from the endosperm of seeds were determined to have $\mathrm{pI}$ values ranging from 6.9 to 8.1 [43].

Plants have many advantages as hosts for recombinant technologies, including the possibility of high yield, freedom 
from animal pathogen contamination, and low production cost overhead $[7,44]$. It is plausible, however, that endogenous protein allergens may be coextracted along with recombinant proteins $[18,22]$. The vicilin glycoproteins from soy beans, pumpkin seeds, and tap roots of carrots compared here have also been identified as allergens, and each of these proteins has a highly conserved peptide sequence (Figure 5). Previously, evidence has been presented to suggest that those individuals presensitized to vicilin proteins from one plant species may be affected by IgE recognition of vicilins derived from these and additional species [20,45]. Although allergy is a function of $\operatorname{IgE}$ antibodies, cross-reactive IgG binding (Figure 6) demonstrates the possibility that antibodies of other classes may bind to epitopes present on $N$. sylvestris protein.

Considerable interest has been given to cross-reactivity of seed proteins in relation to the increasing occurrence of severe allergic reaction [22]. General areas of conserved peptide sequences comprising large domains across the cupin superfamily (e.g., the cupin domains themselves) appear to be similar enough to produce cross-reactivity [22]. Of particular interest is the cross-species similarity of the more carboxy-localized cupin domains (Figure 5). It is tempting to assume that homology alone is a suitable determinant of allergenicity and Ig cross-reactivity, and this has previously been addressed without a firm consensus having been established [18]. It is possible that antibody cross-reactivity in vivo is dependent upon a combination of conformational similarity and sequence homology $[18,22$, $46]$ and not exclusively one or the other. Given the degree of homology between the putative vicilin we have identified from $N$. sylvestris and the other vicilins discussed here, cross-reactivity prediction on the basis of peptide sequence homology alone is reasonable. Our results demonstrating that antibodies against G. max total seed protein also bind to proteins from C. maxima and N. sylvestris are in agreement with the above supposition.

Based on compositional analysis of monosaccharides released by acid hydrolysis, glycosylation of the vicilin-like protein from N. sylvestris is not uniform among subunits and fragments (Figures 3 and 4, Table 2). High molecular mass bands (Figure 3, band A), representative of vicilin monomers not subjected to proteolytic modifications, showed a nearly two-fold presence of GlcN with respect to Man, while the $\sim 22 \mathrm{kDa}$ (Figure 3, band B) fragments separated under reducing conditions produced a GlcN : Man ratio closer to 1 as shown in Table 2. Interestingly, when exposed to antiG. max IgG, the $\sim 22 \mathrm{kDa}$ fragments appeared to stain with greater intensity than the larger $(\sim 50 \mathrm{kDa})$ mass (Figure 6, arrow, lane 3). These bands also stained with Con $\mathrm{A}$ and WGA lectins (Figures 3 and 4). The vicilin Bd 28K from $G$. max was reported to have a dependence upon the $N$-linked glycans attached to that protein in the binding of serum $\operatorname{IgE}$ from patients with G. max allergy [47]. It was determined that the Asn 41 residue of $\mathrm{Bd} 28 \mathrm{~K}$ is glycosylated (this site is shown in Figure 5) and that $\operatorname{IgE}$ binding to the protein appeared to be greatly enhanced by the presence of the $N$ linked oligosaccharide. Later work focusing primarily on the carboxy region of Bd $28 \mathrm{~K}$ and on its proteolytically derived
$23 \mathrm{kDa}$ fragments demonstrated that Asn349 is glycosylated and that sera from G. max-sensitive patients showed reduced binding to fragments produced in E. coli due to the absence of the oligosaccharide [24]. However, recombinant peanut proteins rAra h2 and rAra h3, also produced in E. coli and therefore lacking glycosylation, were found to be allergens comparable to their counterparts naturally produced in peanut seeds $[48,49]$. From these contrasting findings, it may be inferred that epitope similarities between seed proteins which originate both from the amino acid sequence and carbohydrate modifications have the potential to produce an immune response in presensitized individuals.

\section{Abbreviations}

$\begin{array}{ll}\text { CBB: } & \text { Coomassie Brilliant Blue } \\ \text { FPLC: } & \text { Fast protein liquid chromatography } \\ \text { PMSF: } & \text { Phenylmethylsulfonylflouride } \\ \text { HPAEC-PAD: } & \begin{array}{l}\text { High-pH anion exchange } \\ \text { chromatography with pulsed } \\ \text { amperiometric detection }\end{array} \\ & \begin{array}{l}\text { NanoLC/ESI-MS/MS: } \\ \text { Nanoscale liquid } \\ \text { chromatography-electrospray } \\ \text { ionization tandem mass } \\ \text { spectrometry }\end{array} \\ & \begin{array}{l}\text { Sodium dodecyl sulfate } \\ \text { polyacrylamide gel electrophoresis }\end{array} \\ \text { SDS-PAGE: } & \text { immunoglobulin }\end{array}$

\section{Acknowledgments}

J. Q. Gerlach and L. Joshi would like to thank Amy D. Smith, Mostafa Sheykhnazari, Miti Shah, Vinay Nagaraj, Michelle Kilcoyne, and Sasha Daskolova for valuable discussions and analysis advice. P. A. Haynes would like to thank Vicki Chandler and Stuart Bourne for support. Funding for this research was provided by the Biodesign Institute, Arizona State University, the Wallace Research Foundation, and Bio5 Institute.

\section{References}

[1] A. Sorrentino, S. Schillberg, R. Fischer, R. Porta, and L. Mariniello, "Molecular farming of human tissue transglutaminase in tobacco plants," Amino Acids, vol. 36, no. 4, pp. 765772, 2009.

[2] M. D. McLean, K. C. Almquist, Y. Niu, et al., "A human anti-Pseudomonas aeruginosa serotype O6ad immunoglobulin G1 expressed in transgenic tobacco is capable of recruiting immune system effector function in vitro," Antimicrobial Agents and Chemotherapy, vol. 51, no. 9, pp. 3322-3328, 2007.

[3] K. C. Almquist, M. D. McLean, Y. Niu, et al., "Expression of an anti-botulinum toxin A neutralizing single-chain Fv recombinant antibody in transgenic tobacco," Vaccine, vol. 24, no. 12, pp. 2079-2086, 2006.

[4] P. Galeffi, A. Lombardi, I. Pietraforte, et al., "Functional expression of a single-chain antibody to ErbB-2 in plants and cell-free systems," Journal of Translational Medicine, vol. 4, article 39, pp. 1-13, 2006. 
[5] S. Reggi, S. Marchetti, T. Patti, et al., "Recombinant human acid $\beta$-glucosidase stored in tobacco seed is stable, active and taken up by human fibroblasts," Plant Molecular Biology, vol. 57, no. 1, pp. 101-113, 2005.

[6] B. Wagner, K. Hufnagl, C. Radauer, et al., "Expression of the B subunit of the heat-labile enterotoxin of Escherichia coli in tobacco mosaic virus-infected Nicotiana benthamiana plants and its characterization as mucosal immunogen and adjuvant," Journal of Immunological Methods, vol. 287, no. 1-2, pp. 203-215, 2004.

[7] F. Sala, M. Manuela Rigano, A. Barbante, B. Basso, A. M. Walmsley, and S. Castiglione, "Vaccine antigen production in transgenic plants: strategies, gene constructs and perspectives," Vaccine, vol. 21, no. 7-8, pp. 803-808, 2003.

[8] R. G. Birch, "Plant transformation: problems and strategies for practical application," Annual Review of Plant Physiology and Plant Molecular Biology, vol. 48, no. 1, pp. 297-326, 1997.

[9] S. Petruccelli, M. S. Otegui, F. Lareu, et al., "A KDEL-tagged monoclonal antibody is efficiently retained in the endoplasmic reticulum in leaves, but is both partially secreted and sorted to protein storage vacuoles in seeds," Plant Biotechnology Journal, vol. 4, no. 5, pp. 511-527, 2006.

[10] V. Gomord, C. Sourrouille, A.-C. Fitchette, et al., "Production and glycosylation of plant-made pharmaceuticals: the antibodies as a challenge," Plant Biotechnology Journal, vol. 2, no. 2, pp. 83-100, 2004.

[11] E. Stoger, J. K.-C. Ma, R. Fischer, and P. Christou, "Sowing the seeds of success: pharmaceutical proteins from plants," Current Opinion in Biotechnology, vol. 16, no. 2, pp. 167-173, 2005.

[12] T. J. V. Higgins, E. J. Newbigin, D. Spencer, D. J. Llewellyn, and S. Craig, "The sequence of a pea vicilin gene and its expression in transgenic tobacco plants," Plant Molecular Biology, vol. 11, no. 5, pp. 683-695, 1988.

[13] D. A. Goldstein and J. A. Thomas, "Biopharmaceuticals derived from genetically modified plants," QJM, vol. 97, no. 11, pp. 705-716, 2004.

[14] R. L. Freitas, A. R. Teixeira, and R. B. Ferreira, "Vicilin-type globulins follow distinct patterns of degradation in different species of germinating legume seeds," Food Chemistry, vol. 102, no. 1, pp. 323-329, 2007.

[15] P. R. Shewry, J. A. Napier, and A. S. Tatham, "Seed storage proteins: structures and biosynthesis," Plant Cell, vol. 7, no. 7, pp. 945-956, 1995.

[16] M. Sano and N. Kawashima, "Isolation and partial characterization of the major seed protein from Nicotiana tabacum, and the accumulation during development," Agricultural and Biological Chemistry, vol. 47, no. 6, pp. 1305-1310, 1982.

[17] T. Itoh, R. N. Garcia, M. Adachi, et al., "Structure of $8 \mathrm{~S} \alpha$ globulin, the major seed storage protein of mung bean," Acta Crystallographica Section D, vol. 62, no. 7, pp. 824-832, 2006.

[18] J. D. Astwood, A. Silvanovich, and G. A. Bannon, "Vicilins: a case study in allergen pedigrees," Journal of Allergy and Clinical Immunology, vol. 110, no. 1, pp. 26-27, 2002.

[19] R. B. Ferreira, R. L. Freitas, and A. R. Teixeira, "Selfaggregation of legume seed storage proteins inside the protein storage vacuoles is electrostatic in nature, rather than lectinmediated," FEBS Letters, vol. 534, no. 1-3, pp. 106-110, 2003.

[20] R. Sanchez-Monge, G. Lopez-Torrejón, C. Y. Pascual, J. Varela, M. Martin-Esteban, and G. Salcedo, "Vicilin and convicilin are potential major allergens from pea," Clinical and Experimental Allergy, vol. 34, no. 11, pp. 1747-1753, 2004.
[21] T. Fukuda, K. Prak, M. Fujioka, N. Maruyama, and S. Utsumi, "Physicochemical properties of native adzuki bean (Vigna angularis) $7 \mathrm{~S}$ globulin and the molecular cloning of its cDNA isoforms," Journal of Agricultural and Food Chemistry, vol. 55, no. 9, pp. 3667-3674, 2007.

[22] C. Radauer and H. Breiteneder, "Evolutionary biology of plant food allergens," Journal of Allergy and Clinical Immunology, vol. 120, no. 3, pp. 518-525, 2007.

[23] P. E. Gibbs, K. B. Strongin, and A. McPherson, "Evolution of legume seed storage proteins-a domain common to legumins and vicilins is duplicated in vicilins," Molecular Biology and Evolution, vol. 6, no. 6, pp. 614-623, 1989.

[24] M. Hiemori, H. Ito, M. Kimoto, et al., "Identification of the $23-\mathrm{kDa}$ peptide derived from the precursor of Gly m Bd $28 \mathrm{~K}$, a major soybean allergen, as a new allergen," Biochimica et Biophysica Acta, vol. 1675, no. 1-3, pp. 174-183, 2004.

[25] R. Fritsch, H. Ebner, D. Kraft, and C. Ebner, "Food allergy to pumpkinseed-characterization of allergens," Allergy, vol. 52, no. 3, pp. 335-337, 1997.

[26] B. K. Ballmer-Weber, B. Wüthrich, A. Wangorsch, K. Fötisch, F. Altmann, and S. Vieths, "Carrot allergy: double-blinded, placebo-controlled food challenge and identification of allergens," Journal of Allergy and Clinical Immunology, vol. 108, no. 2, pp. 301-307, 2001.

[27] P. R. Shewry and N. G. Halford, "Cereal seed storage proteins: structures, properties and role in grain utilization," Journal of Experimental Botany, vol. 53, no. 370, pp. 947-958, 2002.

[28] K. Adeli and I. Altosaar, "Characterization of oat vicilin-like polypeptides," Plant Physiology, vol. 75, no. 1, pp. 225-227, 1984.

[29] M. M. Bradford, "A rapid and sensitive method for the quantitation of microgram quantities of protein utilizing the principle of protein dye binding," Analytical Biochemistry, vol. 72, no. 1-2, pp. 248-254, 1976.

[30] B. Cooper, D. Eckert, N. L. Andon, J. R. Yates III, and P. A. Haynes, "Investigative proteomics: identification of an unknown plant virus from infected plants using mass spectrometry," Journal of the American Society for Mass Spectrometry, vol. 14, no. 7, pp. 736-741, 2003.

[31] J. K. Eng, A. L. McCormack, and J. R. Yates III, "An approach to correlate tandem mass spectral data of peptides with amino acid sequences in a protein database," Journal of the American Society for Mass Spectrometry, vol. 5, no. 11, pp. 976-989, 1994.

[32] J. R. Yates III, J. K. Eng, A. L. McCormack, and D. Schieltz, "Method to correlate tandem mass spectra of modified peptides to amino acid sequences in the protein database," Analytical Chemistry, vol. 67, no. 8, pp. 1426-1436, 1995.

[33] N. L. Andon, D. Eckert, J. R. Yates III, and P. A. Haynes, "High-throughput functional affinity purification of mannose binding proteins from Oryza sativa," Proteomics, vol. 3, no. 7, pp. 1270-1278, 2003.

[34] J. Peng, J. E. Elias, C. C. Thoreen, L. J. Licklider, and S. P. Gygi, "Evaluation of multidimensional chromatography coupled with tandem mass spectrometry (LC/LC-MS/MS) for largescale protein analysis: the yeast proteome," Journal of Proteome Research, vol. 2, no. 1, pp. 43-50, 2003.

[35] P. A. Haynes, S. Miller, T. Radabaugh, et al., "The wildcat toolbox: a set of perl script utilities for use in peptide mass spectral database searching and proteomics experiments," Journal of Biomolecular Techniques, vol. 17, no. 2, pp. 97-102, 2006.

[36] E. Durr, J. Yu, K. M. Krasinska, et al., "Direct proteomic mapping of the lung microvascular endothelial cell surface in vivo and in cell culture," Nature Biotechnology, vol. 22, no. 8, pp. 985-992, 2004. 
[37] J. G. Rohrbough, L. Breci, N. Merchant, S. Miller, and P. A. Haynes, "Verification of single-peptide protein identifications by the application of complementary database search algorithms," Journal of Biomolecular Techniques, vol. 17, no. 5, pp. 327-332, 2006.

[38] A. A. Schäffer, L. Aravind, T. L. Madden, et al., "Improving the accuracy of PSI-BLAST protein database searches with composition-based statistics and other refinements," Nucleic Acids Research, vol. 29, no. 14, pp. 2994-3005, 2001.

[39] S. F. Altschul, T. L. Madden, A. A. Schäffer, et al., "Gapped BLAST and PSI-BLAST: a new generation of protein database search programs," Nucleic Acids Research, vol. 25, no. 17, pp. 3389-3402, 1997.

[40] R. B. Ferreira, E. Franco, and A. R. Teixeira, "Calcium- and magnesium-dependent aggregation of legume seed storage proteins," Journal of Agricultural and Food Chemistry, vol. 47, no. 8, pp. 3009-3015, 1999.

[41] I. J. Goldstein, "Studies on the combining sites of concanavalin A," Advances in Experimental Medicine and Biology, vol. 55, pp. 35-53, 1975.

[42] A. K. Allen, A. Neuberger, and N. Sharon, "The purification, composition and specificity of wheat-germ agglutinin," Biochemical Journal, vol. 131, no. 1, pp. 155-162, 1973.

[43] I. S. Sheoran, D. J. H. Olson, A. R. S. Ross, and V. K. Sawhney, "Proteome analysis of embryo and endosperm from germinating tomato seeds," Proteomics, vol. 5, no. 14, pp. 3752-3764, 2005.

[44] M. Bardor, G. Cabrera, P. M. Rudd, R. A. Dwek, J. A. Cremata, and P. Lerouge, "Analytical strategies to investigate plant $N$ glycan profiles in the context of plant-made pharmaceuticals," Current Opinion in Structural Biology, vol. 16, no. 5, pp. 576583, 2006.

[45] A. Barre, J.-P. Borges, and P. Rougé, "Molecular modelling of the major peanut allergen Ara h 1 and other homotrimeric allergens of the cupin superfamily: a structural basis for their IgE-binding cross-reactivity," Biochimie, vol. 87, no. 6, pp. 499-506, 2005.

[46] R. C. Aalberse, "Assessment of allergen cross-reactivity," Clinical and Molecular Allergy, vol. 5, article 2, pp. 1-6, 2007.

[47] M. Hiemori, N. Bando, T. Ogawa, et al., "Occurrence of IgE antibody-recognizing $N$-linked glycan moiety of a soybean allergen, Gly m Bd $28 \mathrm{~K}$," International Archives of Allergy and Immunology, vol. 122, no. 4, pp. 238-245, 2000.

[48] P. Rabjohn, E. M. Helm, J. S. Stanley, et al., "Molecular cloning and epitope analysis of the peanut allergen Ara $\mathrm{h} 3$," The Journal of Clinical Investigation, vol. 103, no. 4, pp. 535-542, 1999.

[49] M. P. de Leon, A. C. Drew, I. N. Glaspole, C. Suphioglu, J. M. Rolland, and R. E. O'Hehir, "Functional analysis of cross-reactive immunoglobulin $\mathrm{E}$ antibodies: peanut-specific immunoglobulin E sensitizes basophils to tree nut allergens," Clinical and Experimental Allergy, vol. 35, no. 8, pp. 10561064, 2005. 

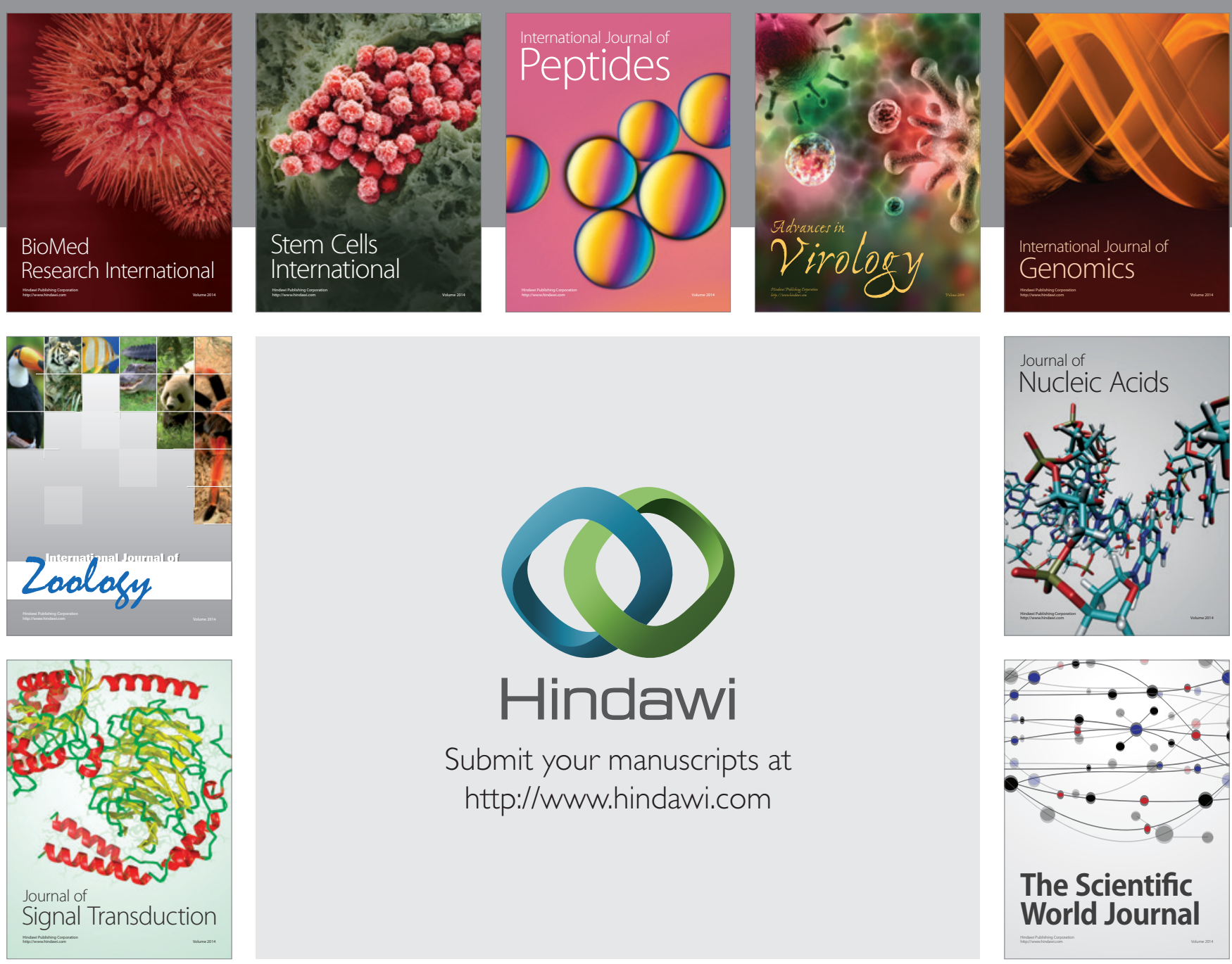

Submit your manuscripts at

http://www.hindawi.com
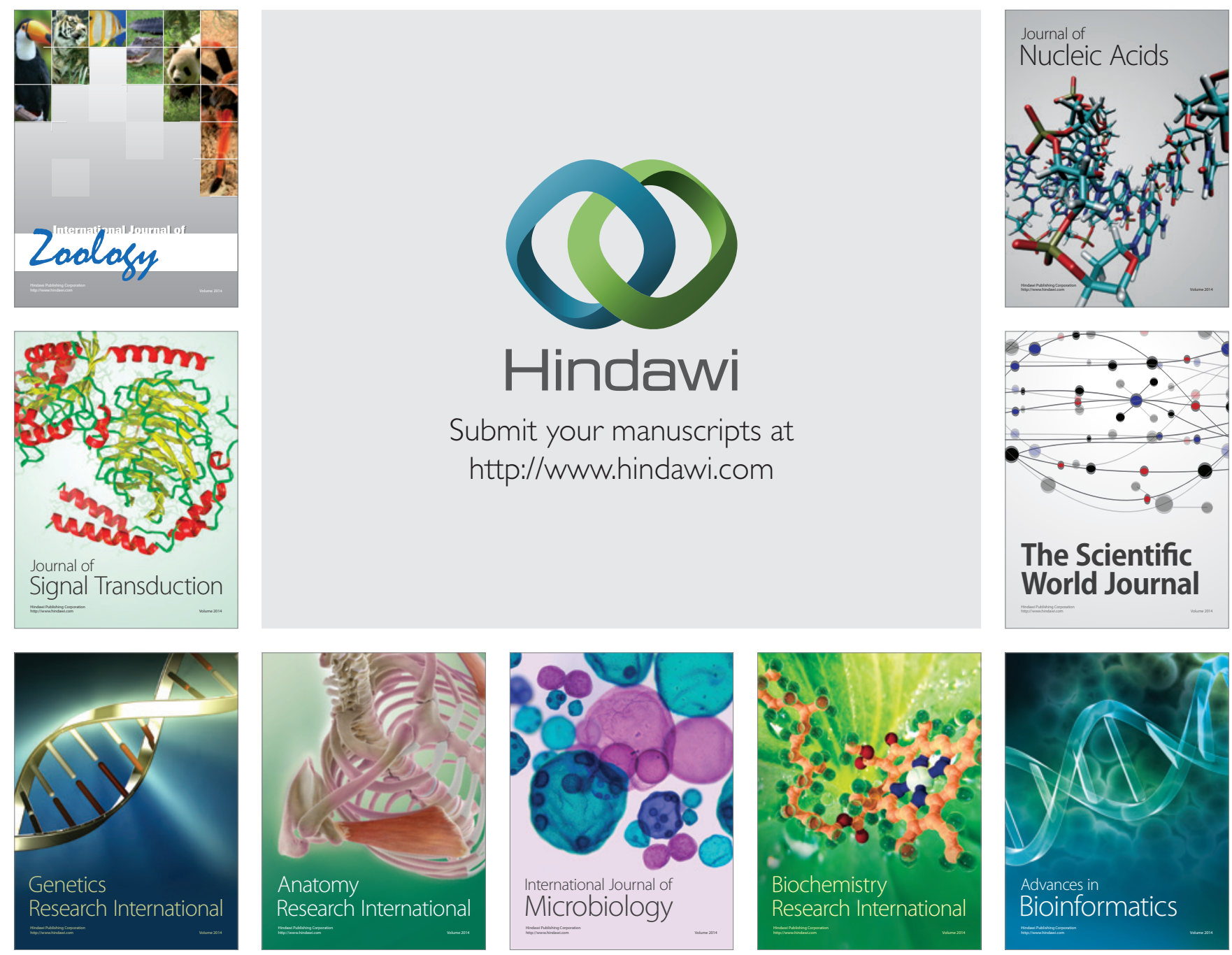

The Scientific World Journal
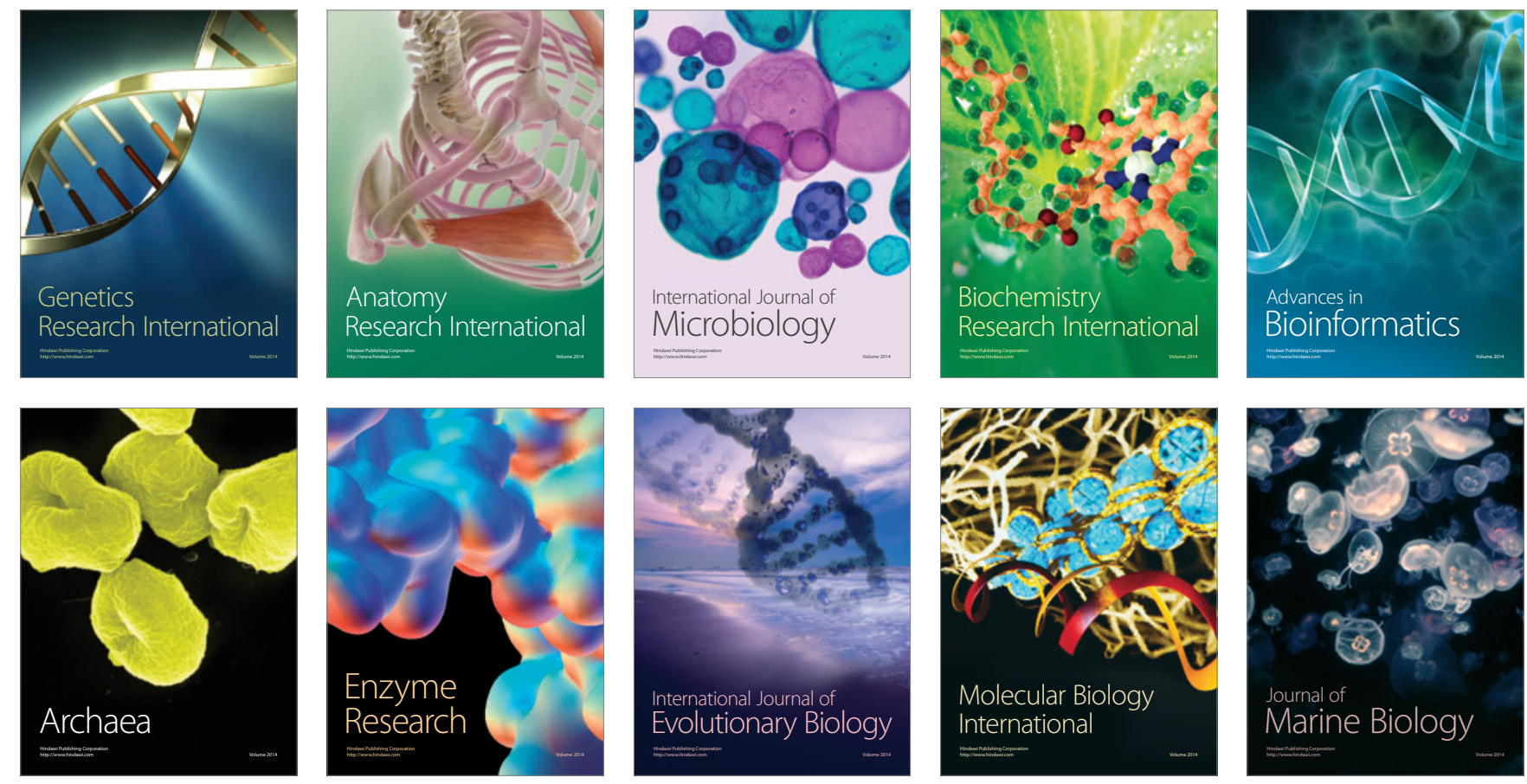